\title{
Popelka na cestě do Bruselu: České skupiny prosazující rovnost mezi ženami a muži a Evropská unie'
}

\author{
Cinderella on the Way to Brussels: Czech Women's Groups \\ and the European Union
}

\author{
Ondřej Císař, Kateřina Vráblíková
}

\begin{abstract}
The goal of this article is to analyze the impact the EU has had on the Czech women's groups since the 1990s. The first section debates possible theoretical approaches to the study of the Europeanization of political activism. The second section describes the transformation of the Czech political opportunity structure induced by the accession process. The third section focuses on the consequences for Czech women's groups of their increased reliance on EU funding. The fourth section analyzes opportunities for transnational cooperation created by the eastward enlargement of the EU. The article concludes by summarizing its main findings.
\end{abstract}

KEY WORDS Europeanization, social movements, EU, women's movement, EWL

\section{Úvod}

Ženské hnutí v České republice tvoří poměrně široká škála různých nevládních organizací a neformálních skupin, které se angažují v otázce postavení žen a mužů ve společnosti. ${ }^{2}$ I přesto, že organizace a skupiny řadící se $\mathrm{k}$ ženskému hnutí začaly vznikat bezprostředně po pádu komunistického režimu, $\mathrm{k}$ jejich výraznější aktivizaci došlo až v druhé polovině 90. let. Spouštěcím mechanismem byl počátek přistupového procesu České republiky (ČR) do Evropské unie (EU), která v oblasti politiky genderu vyžadovala určitá opatření. Cílem tohoto článku je proto analyzovat dopady vlivu EU na sektor českých ženských skupin. ${ }^{3}$

Sociální studia. Fakulta sociálních studií Masarykovy univerzity, 3/2007. S. 107-120. ISSN 1214-813X.

1 Tato stat' byla zpracována $\mathrm{v}$ rámci Výzkumného záměru Politické strany a reprezentace zájmů v soudobých evropských demokraciích (MSM 0021622407).

2 Sociální hnutí chápeme v souladu s vymezením D. della Porty a M. Dianiho jako neformální sítě interakce, které propojují různé organizace a jednotlivce. Sociální hnutí sdílejí společnou identitu a účastní se politických a/nebo kulturních konfliktů, v nichž se snaží prosadit nebo zabránit sociální změně (Della Porta a Diani 1999: 14-15). To, že hnutí vidíme jako sít' interakcí, nám umožňuje zachytit jeho vnitřní komplexitu a nenahlížet jej, jak se často děje, jako homogenní a koherentní skupinu. Ve skutečnosti jsou názory, postoje i činy v rámci hnutí vždy pluralitní, ambivalentní a často protikladné. Studie také užívá pojem, „ženské skupiny“. Termín se vztahuje k tématům ženské a genderové agendy, na nichž skupiny pracují, nijak se nedotýká charakteristiky jejích členů a členek.

3 Tento článek částečně využívá a dále rozvádí dříve publikované texty (viz Císař 2005a, 2005b, Vráblíková 2007). Zdrojem nových informací byly především rozhovory vedené s představitelkami studovaných organizací; jedná se o techniku tzv. elite interview. 
První sekce definuje teoretická východiska naší stati. Vycházíme z teorie evropeizace, kterou však reformulujeme takovým způsobem, aby nám poskytla adekvátní teoretický základ pro studium dopadu (očekávaného) členství v EU jak na strukturu politických institucí, tak také na organizační vývoj a interakce vybrané skupiny politických aktérů. Druhá sekce popisuje proměnu politického kontextu - struktury politických příležitostí v České republice - v souvislosti s př́stupovým procesem. Třetí sekce se zaměřuje na změny ve financování ženských skupin, které od konce 90. let stále více spoléhají na evropské zdroje. Čtvrtá sekce podává analýzu transnacionální spolupráce, pro niž poskytlo nové příležitosti východní rozšíření EU. V této sekci nás bude zajímat, do jaké míry české ženské skupiny těchto příležitostí skutečně využily. V závěru shrneme základní zjištění naší stati.

\section{Evropeizace}

Projevům evropské integrace v členských a přistupujících státech EU - evropeizaci - se od konce 90. let věnuje zvýšená výzkumná pozornost. Na rozdíl od teorie integrace, která se snaží vysvětlit prríčiny integračního procesu, se teorie evropeizace věnuje dopadům tohoto procesu na jeho konstitutivní jednotky - státy a aktéry jednající v jejich rámci. Výzkumný program evropeizace tak představuje pohled „shora“, když jako závislou proměnnou nechápe integrační proces, ale jím způsobené změny v národní politické struktuře a v politikách a interakcích aktérů jednajících v prostředích členských a přistupujících států EU. Podle Radaelliho (2003: 30) je evropeizace tvořena procesy ,a) konstrukce, b) rozšiřování a institucionalizace formálních a neformálních pravidel, procedur, politických paradigmat, stylů, ,metod řešení‘ a sdílených přesvědčení a norem, které jsou nejprve definovány a konsolidovány $\mathrm{v}$ rámci veřejné politiky a politického procesu EU a následně inkorporovány $\mathrm{v}$ rámci domácího diskurzu, identit, politických struktur a veřejných politik“. Podle tohoto přístupu se tak teorie evropeizace, jednoduše řečeno, týká proměny národní politiky v důsledku adaptačního tlaku působícího z EU.

Jiní autoři evropeizaci definují jako konkrétní projev mezinárodní institucionalizace, k níž dochází v evropském prostoru. Evropeizace je zde chápána jako „ustavení a rozvoj zvláštních struktur vládnutí na evropské úrovni. Jedná se jednak o politické, právní a sociální instituce spojené s politickým řešením problémů, které formalizují interakce mezi aktéry, a zároveň o politické sítě, které se specializují na vytváření autoritativních evropských pravidel“ (Risse a kol. 2001: 3). Evropeizace je tak primárně chápána jako rozvoj nové - nadnárodní - struktury politického rozhodování. Podobně jako v př́ípadě Radaelliho je i zde výzkum exkluzivně zaměřen na efekty budování této nové struktury v národních politických prostředích. I tato verze si tak zachovává pohled „shora“ - studuje tlak EU v členských a přistupujících státech. Tento tlak se projevuje jak v jednotlivých politikách (policies), tak také v institucionální struktuře (polity) a politických interakcích (politics) členských zemí EU a zemí ucházejících se o členství (Schimmelfennig 2002, Börzel a Risse 2003, Grabbe 2003).

Tento článek vychází z kriticky reformulovaného modelu evropeizace, který ji konceptuálně neredukuje jen na výše zmíněné působení „shora“ (viz Tarrow 2004, Císař 2005a, 2005b, 2007). Vliv EU totiž vede nejen k proměně domácích pravidel hry a k redistribuci 
zdrojů použitelných $\mathrm{v}$ domácí politické aréně, ale i $\mathrm{k}$ tomu, že určitým skupinám politických aktérů za určitých podmínek umožňuje, aby rozšíríli svůj akční rádius a vstoupili do př́mé interakce bud's evropskými institucemi, nebo s Evropskou unií podporovanými sítěmi nevládních organizací. Jak upozornila teorie víceúrovňového vládnutí již v polovině 90 . let 20. století, politický proces EU je charakterizován vzájemným propojením národních, regionálních a nadnárodních institucí, které umožňují různým politickým aktérům na různých úrovních interagovat a navazovat různé typy koalic (Rucht 2001, Helfferich a Kolb 2001, Martin a Ross 2001, Greenwood 2003). Víceúrovňové politické zř́zení (multi-level polity), které se podle proponentů této teorie zformovalo v podobě EU, poskytuje nové politické prríležitosti, které umožňují kolektivní jednání (respektive prosazování zájmů) na jiné než národní úrovni. Analogicky $\mathrm{k}$ tomu, jak se v návaznosti na rozmach moderního národního státu mobilizovala národní sociální hnutí, očekávají někteří autoři, že v odpovědi na vývoj evropské víceúrovňové polity se rozvine „transnacionální kolektivní jednání“ (Marks a McAdam 1999).

Podle jiných názorů sice nelze díky komplexitě a rozsahu evropské správy očekávat, že by se objevila autentická evropská sociální hnutí, která vyžadují „zapuštěnost“ v domácích sociálních sítích (Imig a Tarrow 2001, Greenwood 2003: 272, Tarrow 2004, Císař 2004), neznamená to však, že by evropská politika měla zůstat prosta vlivu organizovaných zájmů. Evropské instituce poskytují unikátní př́ležitosti pro aktivní strategie prosazování zájmů nejrůznějších skupin a hnutí, které tak evropeizují svoji činnost. Tuto dynamiku výše citovaný Risse a jeho spolupracovníci uchopit nedokáží. Efekty integračního procesu - evropeizace - jsou mnohem komplexnější, než by napovídaly původní modely, snažící se o jeho uchopení a vysvětlení. Ty díky své výzkumné perspektivě brání vidět určitý typ interakcí, které evropeizace teoreticky umožňuje. Evropeizace neovlivňuje závisle proměnnou (státy a aktéry jednající v jejich rámci) pouze $\mathrm{v}$ jedné dimenzi - na domácí úrovni -, ale přivádí do hry dimenzi novou - př́ležitosti transnacionálního jednání. Ty tak představují neodmyslitelnou druhou stranu téže mince procesu evropeizace.

$\mathrm{V}$ našem textu se zaměříme na projevy evropeizace $\mathrm{v}$ oblasti ženské agendy ve dvou rovinách. Jednak budeme sledovat proměnu domácího politického kontextu (polity) v důsledku adaptačního tlaku EU, který byl na Českou republiku vyvíjen v průběhu prístupového procesu. Jazykem teorie kolektivního jednání tak budeme analyzovat interakci domácí a evropské struktury politických př́ležitostí a ukážeme, jak EU postupně otevírala politické př́ležitosti v domácí struktuře (srov. Sikkink 2005). Dále budeme zkoumat projevy evropeizace v dimenzi politických interakcí (politics). Zde se na jedné straně zaměříme na dopady evropeizace na organizační vývoj ženských skupin, k němuž ve druhé polovině 90 . let příspěla proměna kontextu jejich financování, ve kterém začala hrát čím dál větší roli právě EU. Na druhé straně nás bude zajímat transnacionální jednání českých ženských skupin, a to jak ve smyslu interakce s institucemi EU, tak s ohledem na spolupráci s Evropskou unií podporovanými sítěmi nevládních organizací. V našem článku se tak nezaměřujeme pouze na prímý dopad př́stupového procesu, ale sledujeme také další neméně zásadní změny, které s sebou tento proces a následný vstup do EU přinesl. Vzhledem $\mathrm{k}$ tomu, že nás primárně zajímá analýza dopadu evropeizace na vybranou skupinu nestátních aktérů, ponecháváme stranou zhodnocení vlivu evropeizace na obsah státních politik (policy) týkajících se genderové problematiky (k tomuto tématu viz např́ílad Lorenz-Meyer 2003). 


\section{Kontext}

Politické př́ležitosti pro aktéry prosazující rovnost mezi ženami a muži byly v českém prostředí do konce devadesátých let uzavřené. Otázka rovnoprávnosti mužů a žen nepředstavovala pro politickou elitu relevantní politický problém. S nástupem vlád sestavovaných ODS se navíc uzavřely institucionální př́iležitosti pro všechny advokační nestátní organizace (srov. Frič 2001). Proměnu politických příležitostí v oblasti ženských práv tak přinesl až př́istupový proces. Když ČR začala př́stupové rozhovory, probíhal v EU tzv. Čtvrtý stř̌ednědobý akční program pro rovné př́ležitosti mužů a žen naplánovaný na období let 1996-2000. ${ }^{4}$ Zároveň s tím se ČR zavázala plnit doporučení 4. Světové konference OSN o ženách, která proběhla $\mathrm{v}$ roce $1995 \mathrm{v}$ Pekingu. ${ }^{5}$ Byl to tak tlak mezinárodních organizací, hlavně EU, který v ČR v námi studované oblasti „přenesl“ a otevřel politické př́ležitosti.

Poprvé se česká vláda začala zabývat ženskou agendou v záŕí 1997, kdy došlo k ustavení Mezirezortní komise pro postavení mužů a žen (Marksová-Tominová 1999). Počátkem roku 1998 byl koordinací této politiky pověřen ministr práce a sociálních věcí a současně bylo všem vládním resortům uloženo spolupracovat s ženskými nevládními organizacemi. Nutnost harmonizace právních předpisů ČR a EU vyústila v další institucionální kroky: v rámci Ministerstva práce a sociálních věcí došlo ke zřízení Oddělení rovnosti mužủ a žen, které vypracovalo a předložilo návrh vládního prohlášení „Priority a postupy vlády při prosazování rovnosti mužů a žen“ - první oficiální dokument zabývající se ženskou agendou vůbec (Musilová 1999). Na prŕípravě tohoto dokumentu se podíleli i zástupci ženských neziskových organizací a česká vláda jej použivala jako součást přístupových rozhovorů pro vstup do EU.

Stejným směrem pokračovala i sociálně-demokratická vláda vzešlá z červnových voleb roku 1998. Politiku rovných př́ležitostí žen a mužů chápala jako součást politiky lidských práv. Když byla $\mathrm{v}$ prosinci ustavena Rada vlády ČR pro lidská práva, do její působnosti bylo v rámci sledování a vyhodnocování stavu dodržování lidských práv výslovně zahrnuto i vyhodnocování plnění mezinárodních závazků, včetně Úmluvy OSN o odstranění všech forem diskriminace žen. V lednu 2002 byla jedna z jejích poradních sekcí přejmenována na Výbor pro odstranění všech forem diskriminace žen. V sekci nalezli své zastoupení reprezentantky ženských neziskových organizací, zástupci př́slušných ministerstev a odborné veřejnosti.

K podobnému vývoji došlo koncem 90. let také v Poslanecké sněmovně. V září 1998 byl z iniciativy poslankyně J. Volfové (ČSSD) a za aktivní účasti Českého svazu žen založen parlamentní Podvýbor pro rovné př́ležitosti a otázky rodiny Výboru pro sociální politiku a zdravotnictví. Kromě poslanců byly členy tohoto podvýboru i zástupkyně ženských neziskových organizací (Marksová-Tominová 1999).

Vládní rozhodnutí 456/2001 dále zavázalo každé ministerstvo jmenovat jednoho státního úruredníka nebo úrurednici, kteří budou na jednotlivých ministerstvech působit jako osoby koordinující rovné př́ležitosti v oblasti působnosti daného ministerstva. Institucionální ukotvení regulí EU do českého prostředí se dovršilo v ř́ijnu 2001 zřízením samostatné Rady vlády

$4 \quad$ O politice gender rovnosti v EU a ČR do roku 1999 viz Musilová 1999.

5 Akční platforma čtvrté světové konference OSN o ženách v Pekingu schválila strategii gender mainstreamingu (viz dále) (Musilová 1999). 
pro rovné př́ležitosti mužů a žen, kde vedle zástupců ministerstev zasedli reprezentanti ženských neziskových organizací spolu s delegací zaměstnavatelů, odborů a Českého statistického úřadu (Linková 2003). Důležitým spojencem při implementaci ženské agendy byl ministr práce a sociálních věcí a pozdější premiér V. Špidla. Navzdory negativním postojům svých spolustraníků inicioval vznik Rady vlády pro rovné př́iležitosti (tamtéž).

Základem evropské politiky rovných př́ležitostí je tzv. gender mainstreaming, což v praxi znamená systematickou integraci rovných př́ležitostí a principu rovnosti do všech politik, programů a projektů členských státu (Musilová 1999). EU prosazuje v tomto směru určitá konkrétní témata. Téma diskriminace na základě genderu na pracovním trhu, problematika domácího násilí a otázka slad’ování profesního a rodinného života žen a mužů byly díky tlaku EU přeneseny na národní úroveň a uznány v českém prostředí jako relevantní politické problémy. Teprve př́stupový proces jim tak propůjčil politický význam, ačkoli je po celá devadesátá léta prosazovaly i místní ženské skupiny. V kontextu př́istupového procesu ztratila témata domácího násilí a platové diskriminace na pracovním trhu svou „feministickou“ nálepku a začala být nahlížena jako „sociální problémy“. Ostatní otázky - jako asymetrická mocenská struktura (zavedení kvót na vedoucí pozice) či jiná témata vycházející z prosazování ženských práv - byly státní administrativou vnímány jako nepodstatné či - jako v př́ípadě sexuálního obtěžování - byly dokonce karikovány (Linková 2003).

Na základě výše uvedeného můžeme říci, že EU v ČR devadesátých let (a to nejen v kontextu politiky rovnosti žen a mužů) fungovala jako „certifikační agentura“, jejíž politika rozhodovala o uznání, respektive neuznání určitých politických požadavků jako skutečně relevantních. Toto působení evropeizace shora lze popsat právě pomocí kauzálního mechanismu „,ertifikace“, jímž v souladu se současnou teorií kolektivního jednání chápeme „,signál nějaké externí autority o tom, že je připravena uznat a podpořit existenci a požadavky nějakého politického aktéra“ (Tilly a Tarrow 2007: 215). České ženské skupiny získávaly př́stup do politického systému až v souvislosti s tlakem, který na relativně uzavřenou domácí strukturu politických př́ležitostí vyvíjela nejdůležitější externí agentura v regionu - EU.

\section{Organizační vývoj}

Vedle vlivu, který EU vyvíjela na politické instituce, $v$ jejichž rámci české ženské skupiny jednaly, také prŕmo ovlivňovala organizační vývoj těchto skupin. Podobně jako v jiných sektorech politického aktivismu (např́íklad environmentálním) byly české ženské skupiny od počátku 90 . let, kdy začaly vznikat, závislé na externím financování skrze nejrůznější zahraniční nadace. (Dalším nezbytným zdrojem byla dobrovolnická práce.) Zatímco na počátku 90. let byly ženské organizace financovány především ze zdrojů amerických nadací a jednotlivých evropských států, ke konci 90. let, v souvislosti s tím, že ČR začala být vnímána jako konsolidovaná demokracie na cestě ke svému začlenění do EU, tyto nadace své programy uzavřely nebo výrazně omezily (viz Mareš a kol. 2006). V této chvíli se staly dominantním potenciálním zdrojem financování EU a její programy. S tím souvisela celá řada změn týkajících se strategie získávání financí, ale také vlastní organizační struktury skupin, jejich tematického zaměření a také celkového fungování sektoru českých ženských organizací (Hašková 2005). 
Původní organizační podoba většiny skupin, která byla spojena se způsobem jejich financování v 90. letech, nedosahovala vysoké úrovně formalizace. Jednalo se většinou o malé skupiny, které tvořilo deset či dvacet lidí s např́ílad jen dvěma aktivními členkami. Tyto ženské skupiny byly schopny získat prostředky na svi̊j provoz právě díky flexibilitě programů financovaných zahraničními nadacemi, jež nepodporovaly pouze konkrétní projekty, ale poskytovaly také peníze, které mohly být použity př́imo na organizační rozvoj (tamtéž).

Koncem 90 . let se prakticky jediným zdrojem financí staly fondy EU. V návaznosti na to se fungování českých ženských skupin razantně změnilo. Peníze získávané z EU jsou vázány na partikulární témata, jsou časově omezené a přesně definují objekt čerpání. Navíc je získání takto vymezených grantů podmíněno formálním statutem žadatelů (Hašková 2005, Hašková a Křížková 2006: 93). Organizace musejí splnit celou řadu formálních kriteríi a přizpůsobovat se požadavkům EU v různých dimenzích: podobou organizační struktury, tematickým zaměřením, spoluprací s jinými organizacemi atd.

V praxi to znamená, že proto, aby se skupiny mohly ucházet o „evropské peníze“, musely profesionalizovat a „projektifikovat" své aktivity. Pouze formálně registrované skupiny s dostatečně rozvinutou organizační kapacitou (stabilní organizační a finanční zázemí, zaměstnanci na úvazcích) mohou uvažovat o financování z EU. Odpovídající organizační kapacita jim zároveň umožňuje přizpůsobovat se požadavkům evropských grantů. Organizace potřebují kontinuální financování, k dispozici jsou však pouze peníze na projekty, a proto jsou nuceny skrývat náklady, které nejsou spojeny s projektem, o nějž se právě ucházejí, do nákladových položek žádosti o daný projekt. Administrativní náročnost projektů EU je tak mnohem vyšší, než tomu bylo v případě amerických nadací, přesto však tyto projekty přinášejí srovnatelné výsledky (interview 2).

Tlak EU se netýká, jak již bylo řečeno, pouze managementu činnosti organizací, ale také cílů, které tyto organizace sledují (Hašková a Kolářová 2003). Aby zajistily své přežití, tj. získaly grant z EU, musejí naplnit požadavky EU nejen z hlediska formálního chodu organizace (organizačních kapacit), ale také ve smyslu svého obsahového zaměření. Projekty jsou totiž vypisovány na konkrétní témata, která odpovídají prioritám EU v oblasti rovných príležitostí. Jím je v současné době program gender mainstreamingu. Jinými slovy řečeno, pokud chtějí organizace na dotační tituly EU dosáhnout, musejí přijmout předepsaná témata gender mainstreamingu. Organizace, které nechtěly či nebyly schopny svou agendu přizpůsobit, zanikly. Ty, které přežily, se bud’ těmto tématům již dřive věnovaly, anebo se přizpůsobily: transformovaly svou agendu, musely zaměstnat více lidí, postavit do svého čela profesionální fundraisery a zaměřit se na usilování o granty a navazování kontaktů se státní správou, která dané fondy přerozděluje (Hašková a Kř̌žzová 2006: 95).

Přibližně do roku 2006 se zdálo, že finanční mechanismy evropeizačního tlaku netransformovaly organizační strukturu českých ženských skupin plošně, ale vnesly do sektoru jakousi dělící linii. Vedle postupně se profesionalizujících organizací zde zůstaly skupiny, které cestu proměny $\mathrm{v}$ intencích požadavků EU nechtěly či z kapacitních důvodů nemohly sledovat. Jednalo se o skupiny, jejichž tematický okruh nezapadal do témat tehdy podporovaných EU, což byly např. ekofeministické skupiny (viz Kapusta-Pofahl a kol. 2005) nebo organizace, které neměly dostatečné organizační kapacity - např. Informační centrum NORA (viz Císař a Vráblíková 2006). Na druhé straně díky formalizaci většiny stávajících organi- 
zací vznikly úplně nové skupiny a iniciativy, které tento trend programově odmítaly. Byly to neformální či radikální feministické skupiny, které se nechtěly ucházet o velké granty a „prorůst“ se státní správou. Financování EU tak původně působilo jako diferenciační faktor, který od sebe odděloval na jedné straně formalizované organizace schopné získat finanční podporu a zároveň se zapojit do politického procesu a na straně druhé ty skupiny, které $\mathrm{k}$ těmto zdrojům př́stup neměly, se státní správou nespolupracovaly a jejich strategický repertoár měl tě̌žšstě spiše v prímé akci (Kolářová 2004, Vráblíková 2007). V současnosti se trend proměňuje. Téměř všechny existující organizace se postupně napojily na politiku EU. Jedinou výraznější platformou, která stojí vně evropských programů, je dnes Anarchofeministická skupina.

K restrukturaci sektoru českých ženských skupin došlo i v rovině jejich vzájemných vztahů. Během 90. let nevytvořily české ženské skupiny zastřešující organizaci, jako tomu bylo v jiných sektorech (např́ílad SOHO u gay a lesbického hnutí). Jejich aktivity byly fragmentované a širší koalice byly ustavovány pouze na základě konkrétních témat či podle ideových zaměření. Až v důsledku př́istupového procesu došlo i v sektoru českých ženských skupin $\mathrm{k}$ tvorbě platforem snažících se reprezentovat co nejširší pole různých organizací. První odpovědí na otevírající se příležitosti v českém politickém systému vlivem tlaku EU (viz sekce Kontext) byla zastř̌šující organizace Asociace pro rovné př́ležitosti (APR). Organizace vznikla v roce $1998 \mathrm{~s}$ tím, že měla představovat jednotného partnera pro politickou reprezentaci (Marksová-Tominová 1999). Danou roli po určitou dobu více méně plnila ve vztahu $\mathrm{k}$ Radě vlády pro rovné príležitosti mužů a žen. Tato zastř̌šující organizace ale nezahrnovala všechny významné hráče sektoru. Český svaz žen $(\check{C} S Z ̌)^{6}$ a Unie katolických žen (UKŽ) nebyly její součástí. Z důvodu nedostatečných organizačních kapacit nebyla APR svému záměru účinně prosazovat zájmy ženských skupin schopna dostát, takže se stala v podstatě „mrtvou“ organizací. Role zastřešující organizace přešla na členskou organizaci Evropské ženské lobby - Českou ženskou lobby. Oproti APR zde právě organizace ČSŽ a UKŽ představují jedny z klíčových členů.

V souladu s reformulovaným modelem evropeizace tak můžeme říci, že tlak či spíše „atraktivita“ otevřených př́ležitostí na evropské úrovni měly za následek vytvoření skutečné zastř̌šující organizace českých ženských skupin. Až díky tomuto „tlaku“ či „,pritažlivosti“ otevřených př́ležitostí se $\mathrm{v}$ jedné platformě sešly skupiny, které se po celá 90 . léta vůči sobě spíše vymezovaly, než aby pomýšlely na možná spojenectví. Této dimenzi evropeizace se věnujeme v následující sekci.

\section{Transnacionální vazby}

Evropeizace se neprojevuje pouze ve výše diskutovaných formách př́mého dopadu přístupového procesu na politické instituce národních států a financování nestátních aktérů. Potenciální proměnu politického jednání s sebou přinášejí také nové př́ležitosti, které se

6 ČSŽ byl po celá devadesátá léta ostatními organizacemi ze spolupráce vylučován, a to z politických důvodů, kdy byl ostatními ženskými organizacemi nahližen jako „komunistický pohrobek“ (Marksová-Tominová 1999). 
skupinám politických aktérů $\mathrm{v}$ členských státech EU otevírají díky možnostem spolupráce na evropské úrovni. $V$ př́ípadě politiky rovných př́ležitostí mužů a žen se jedná především o celoevropskou platformu European Women's Lobby (EWL), která byla v roce 1990 založena jako výsledek kombinace politické mobilizace „zdola“ a aktivismu Evropské komise v této politické oblasti (interview 1). V současné době organizace sdružuje 4000 ženských skupin a snaží se vystupovat jako jejich reprezentantka v evropských záležitostech. Cílem organizace je „dosáhnout rovnosti mezi ženami a muži, eliminovat všechny formy diskriminace proti ženám, zajistit respektování ženských lidských práv, vymýtit násilí na ženách a konečně zajistit, aby byla gender rovnost vzata v úvahu ve všech politikách Evropské unie“ (EWL 2007). Za svůj největší dosavadní úspěch organizace považuje lobbyistickou kampaň spuštěnou před uzavřením Amsterodamské smlouvy (1997), díky níž se do výsledného dokumentu dostala důležitá opatření v oblasti rovnosti žen a mužů a diskriminace žen mimo pracovní trh. Články 2 a 3 smlouvy zakotvily výše zmíněný gender mainstreaming (k analýze kampaně viz Helfferich a Kolb 2001).

Členskou základnu EWL tvoří na jedné straně národní platformy (national co-ordinations) a na straně druhé evropské organizace jako napr. European Federation of Business \& Professional Women, European Disability Forum a International Alliance of Women. Členská základna se setkává jednou ročně v rámci valného shromáždění organizace, které rozhoduje o strategickém programu činnosti EWL a jejím financování a každé dva roky volí organizační radu (Board of Administration). Rada se schází čtyřikrát ročně a přijímá taktická rozhodnutí. Každé dva roky pak volí exekutivu EWL, která sestává z prezidentky, trrí viceprezidentek a pokladnice. Tento orgán se schází pravidelně, přijímá bezprostřední rozhodnutí nutná pro rrízení organizace a reprezentuje EWL navenek. Činnost organizace je koordinována jejím bruselským sekretariátem, který připravuje poziční dokumenty, zajišt'uje informační servis členské základně, navazuje kontakty s evropskými institucemi, ř́íí projekty a připravuje publikační a informační materiály (odstavec vychází z EWL 2007). V následujícím textu se zaměříme především na působení EWL na české ženské skupiny.

Politická činnost EWL do velké míry závisí na koordinaci jejích členských skupin. Bruselský sekretariát organizace v létě roku 2006 tvořilo 11 osob (interview 1). Organizace je z 80 procent financována z EU. Její zdroje jsou však poměrně omezené. Také z tohoto důvodu se její činnost, jak již bylo řečeno, zaměřuje pouze na monitoring a ovlivňování evropských institucí a informační servis poskytovaný členským organizacím. Robustní lobbying evropská kancelář z vlastních zdrojů zajistit nemůže. Jak dokládá prŕíklad relativně úspěšné kampaně spuštěné před uzavřením Amsterdamské smlouvy (Helfferich a Kolb 2001) i r̆ada jiných méně výrazných akcí (interview 1), jádro politické práce zůstává vzhledem $\mathrm{k}$ důležitosti, kterou $\mathrm{v}$ evropské politice stále hrají jednotlivé státy, na národní úrovni. EWL tak v př́padě lobbyistických kampaní koordinuje „víceúrovňovou strategii“: bruselská kancelář využívá svých kontaktů především v Evropské komisi, zatímco její členské organizace se na národní úrovni zaměřují na ovlivňování „svých“ politických institucí a poslanců Evropského parlamentu zvolených $\mathrm{v}$ jejich zemi. Podle bývalé úřadující generální tajemnice EWL Cécile Gréboval „máme jakési vzorové dopisy, které naše členské organizace mohou použít [pro oslovení] svých lidí i poslanců Evropského parlamentu a vlastních vlád tak, že je mohou přeložit a informovat tyto různé jednotlivce na různých úrovních o pozici $[\mathrm{EWL}][\ldots]$ 
snažíme se vytvořit tuto souhru mezi národní úrovní, evropskou úrovní, jednotlivými členy Evropského parlamentu atd.“(tamtéž).

Je jen logické, že v souvislosti s rozšiřováním EU také EWL rozšiřuje svůj záběr a snaží se do své sítě integrovat skupiny z nově přistupujících zemí. Tento postup byl v 90 . letech $\mathrm{s}$ různou mírou úspěšnosti aplikován také $\mathrm{v}$ případě východoevropských kandidátských zemí včetně České republiky. Rozšiřrování EU pro EWL znamená rozšiřování její vlastní sítě. $\mathrm{V}$ prŕípadě východního rozšíření tento proces zabral přibližně dva až tři roky. EWL nejprve sbírala informace „o existujících organizacích, abychom se s nimi mohly setkat, shromáždit je, [...] informovat je o EWL a zjistit, jak by se mohly organizovat. [...] přišly jsme tam [do kandidátských zemí], zorganizovaly mezinárodní setkání nebo skrze školení, které jsme tam organizovaly..." (tamtéž). Cílem EWL bylo motivovat vytvoření širokých národních platforem, které by zahrnuly co nejvíce existujících ženských skupin. Formálně je tento proces završen podpisem protokolu o spolupráci a volbou národních zástupkyň do EWL. Tyto reprezentantky jsou celkem čtyři, národní platforma ženské lobby volí tři delegátky do valného shromáždění a jednu osobu do organizační rady EWL (tamtéž).

V ČR se o založení národní platformy EWL začalo uvažovat v roce 2004, kdy byly položeny základy České ženské lobby (Czech Women 's Lobby, ČŽL). Zapojení českých ženských organizací do lobbyistických struktur EU bylo podmíněno, jak již bylo řečeno, utvořením co nejširši platformy. V jejím rámci se tak sešly organizace, které do té doby spojenectví netvořily: vedle Unie katolických žen či Gender Studies o.p.s. stál i doposud vyloučený Český svaz žen. ČSŽ totiž i přes svoji původně pro ostatní organizace nepřijatelnou politickou minulost zůstal díky svému početnému členstvu a organizačnímu zázemí jedním z nejsilnějších hráčů českého ženského sektoru. Při ustavování národní platformy jej tak již nebylo možné ignorovat. První předsedkyní neformálního uskupení ČŽL se stala R. Boháčová z Unie katolických žen. Platforma měla zpočátku jen status pozorovatele při EWL, s přibývajícím členstvem se ČŽL stala roku 2005 plnoprávným členem se všemi právy a povinnostmi. ${ }^{8}$

Členem ČŽL se může stát jakákoli česká organizace, která je zaměřená na ženská témata a ztotožňuje se s cíli EWL, tj. deklaruje se víceméně jako feministická organizace. Nová organizace je do ČŽL přijata, pokud její přistoupení odsouhlasí stávající členské skupiny. V současnosti je platforma tvořena 21 organizacemi a její složení je skutečně různorodé. Vedle již zmíněných subjektů jsou členy např́klad skupiny romských žen, organizace zaměřené na pomoc prostitutkám, iniciativy pomáhající obětem domácího násilí či sdružení podnikatelek (Fórum 50\% 2007). Zástupkyně členských organizací volí na valném

7 Indikátorem síly evropeizačního tlaku je bezpochyby i skutečnost, že některé ženské organizace (zejména Gender Studies o.p.s.) stály v roce 1997 u zrodu mezinárodní koalice středovýchodních ženských skupin Karat Coalition, která byla do jisté míry chápána jako konkurenční subjekt EWL. Karat však nebyl schopen etablovat se jako vlivná mezinárodní organizace. Ani jeho členské skupiny tak nemohly jít proti proudu evropeizačního tlaku a byly „,přinuceny“ přistoupit na sdružování v rámci EWL.

8 Hlavní povinností členských organizací je platit roční příspěvek. Splnění tohoto požadavku není pro organizace snadnou záležitostí, protože, jak zmínila předešlá kapitola, většina z nich je financována skrze projekty podporované EU, které mají přesně určené čerpání přidělených prostředků. Organizace tak v podstatě nemají žádné volné prostředky, které by na tyto poplatky mohly použit. 
shromáždění jednou za dva roky předsedkyni a její zástupkyně, které reprezentují ČŽL na úrovni EWL.

I nadále je ČŽL neformální platformou bez právní subjektivity, což do značné míry omezuje její manévrovací schopnost. Platforma se potýká s nedostatkem finančních zdrojů, organizačně ve skutečnosti zatím existuje jen jako „př́ivěsek“ té ženské organizace, v níž pracuje její předsedkyně - nejprve Unie katolických žen, poté Gender Studies o.p.s. a nyní Fóra $50 \%$. Finanční zdroje organizace představují členské př́íspěvky a účastnické poplatky valného shromáždění. Jediný projekt, který ČŽL doposud realizovala, byl koordinovaný EWL a zaměřoval se na prostituci. $\mathrm{V}$ tomto př́padě lze hovořit o evropeizaci agendy organizace ve formě difúze (Tarrow 2005: 104) priorit EWL na národní úroveň, nebot' jak upozorn̆uje bývalá předsedkyně ČŽL, téma samotné nebylo v ČR pocit’ováno jako prioritní: „Protože samožrejmě cílem EWL je kriminalizace nákupu prostituce, což nebylo úplně jakoby naším cílem a vlastně to vyvolalo takovou jakoby diskuzi o tom tématu, o tom, co ty ženy a tak dále a to byl vlastně jedinej projekt, kterej Česká ženská lobby tehdy realizovala..." (interview 2). Vedle toho je ČŽL jako národní platforma zahrnuta do pravidelného informačního servisu EWL (pět až deset e-mailů denně) a usiluje o aktivní zapojení do př́pravy pozičních dokumentů EWL, i když její schopnost systematické politické práce ztěžují velmi omezené zdroje. Řečeno slovy teorie kolektivního jednání, ačkoli př́ležitosti (zapojit se skrze EWL do evropského politického procesu) existují, národní platformě chybí organizační kapacita těchto příležitostí skutečně využít.

Díky ideologické heterogenitě organizací sdružených v ČŽL a rozhodovací proceduře, která je založena na konsensu, se rozhodování v rámci české platformy realizuje skrze hledání nejmenšího společného jmenovatele. V situacích, kdy nelze na úrovni ČŽL konsensus najít, se organizace zdrží hlasování na úrovni evropské. Bylo tomu tak například v případě reprodukčních práv či otázky stejnopohlavních párů, kdy se zástupkyně ČŽL na evropském valném shromáždění hlasování v těchto otázkách zdržely (interview 2). Organizace, které přesto chtějí podpořit témata, pro něž nelze $\mathrm{v}$ rámci ČŽL najít shodu, mohou zvolit cestu individuální podpory a zapojit se do určité transnacionálně koordinované kampaně samostatně. Takovým př́kladem byla kampaň portugalské platformy směřující proti kriminalizaci potratů v Portugalsku. Platforma usilovala o získání podpory ostatních členských organizací EWL. Jelikož si české skupiny, které chtěly tuto kampaň podpořit, byly vědomy toho, že $\mathrm{v}$ rámci ČŽL není možné dosáhnout ve vztahu $\mathrm{k}$ tomuto tématu konsensu, zvolily cestu lobbyingových dopisů psaných za jednotlivé organizace a ne jménem ČŽL (tamtéž).

Stejným způsobem se na EWL obrací i české organizace. Př́íkladem takové snahy využít aktivně členství v EWL může být kampaň Gender Studies o.p.s. za prosazení Mezinárodního dne rovnosti, v níž počítá také s podporou členských skupin EWL v jiných zemích EU.

\section{Závěr}

$\mathrm{V}$ našem textu jsme se zaměřili na projevy evropeizace aktivismu ženských skupin v ČR. Nejprve jsme upozornili na určitá omezení převládající teorie evropeizace a navrhli její reformulaci tak, abychom byli schopni analyzovat nejen bezprostřední dopad evropeizace na národní úrovni, ale také projevy zapojování domácích skupin do evropského politického 
procesu. Proměnu strategií politického jednání místních skupin považujeme za nedílnou součást dopadů evropeizace. Ve zbytku textu jsme analyzovali evropeizaci ve dvou dimenzích politiky.

Zaměřili jsme se na proměnu institucionálního kontextu (polity) a na proměnu jednání ženských organizací v důsledku změněných mechanismů financování a nastolení otevřených př́ležitostí pro navazování transnacionálních vazeb na evropské úrovni (politics).

V kontextuální dimenzi jsme pozorovali postupné otevírání domácí struktury politických př́ležitostí v návaznosti na požadavky, které na ČR kladla EU během př́stupového procesu. Výsledkem bylo vytvoření několika př́stupových bodů do politického systému, skrze něž mohly ženské organizace od konce 90 . let vstoupit do politického procesu. EU zároveň působila jako certifikační agentura, jejíž vliv pomohl legitimizovat požadavky ženských skupin $\mathrm{v}$ očích představitelů politické elity.

Efekty evropeizace jsme pozorovali také $\mathrm{v}$ důsledku rostoucího významu, který EU začala hrát ve struktuře financování místních organizací. Tento tlak vedl k profesionalizaci a formalizaci jednání téměř všech organizací. EU však neovlivňovala české skupiny pouze skrze požadavky, které kladla na státní instituce, a skrze granty, které rozděluje.

Rozšiření EU přineslo ženským skupinám nové př́ležitosti ve formě jejich možného zapojení se do evropského politického procesu skrze EWL. Požadavky členství v této celoevropské síti ženských organizací přinesly do domácího ženského aktivismu integrační impulsy a motivovaly ke spolupráci i dř́ve konkurenční skupiny. Členství v EWL dále poskytlo možnosti využít podpory ženských organizací z jiných členských států EU pro iniciativy místních organizací. Tohoto potenciálu jsou však díky omezeným organizačním zdrojům české skupiny schopny využít zatím jen v omezené míre.

\section{Literatura}

Börzel, T.; Risse, T. 2003. „Conceptualizing the Domestic Impact of Europe.“ In K. Featherstone a C. M. Radaelli (eds.) The Politics of Europeanization. Oxford, New York: Oxford University Press, s. 57-80.

Císar̆, O. 2004. Transnacionální politické sitě: Jak mezinárodní instituce ovlivňují činnost nevládnich organizací. Brno: IIPS.

Císař, O. 2005a. „Evropeizace a obhajoba zájmů: základy analytického rámce.“ In: Evropeizace: Nové téma politologického výzkumu, eds. B. Dančák, B., P. Fiala, V. Hloušek. Brno: IIPS, 54-71.

Císař, O. 2005b. „Sociální hnutí, nevládní organizace a zájmové skupiny ve víceúrovňové struktuře EU: přístup ke studiu.“ In: P. Fiala, M. Strmiska (eds.) Viceúrovňové vládnutí: teorie, prístupy, metody. Brno: CDK, 214-231.

Císař, O. 2007. „Between the National and Supranational? Transnational Political Activism, Conflict, and Cooperation in the Integrated Europe.“ Contemporary European Studies 2 (1): 21-36.

Císař, O.; Vráblíková, K. 2006. „Občanská společnost v Brně.“ In: S. Balík a kol. Lokální politický pluralismus: Brno ve třech stoletích. Brno: CDK, 111-136.

Della Porta, D.; M. Diani. 1999. Social Movements: An Introduction. Oxford, Malden, Blackwell. 
EWL 2007. Oficiální webová prezentace EWL. Dostupné na: http://www.womenlobby.org/ site/hp.asp?langue=EN [citováno dne 20. 4. 2007].

Fórum 50\% 2007. Česká ženská lobby (CŽL). Dostupné na: http://www.padesatprocent.cz/ ceska-zenska-lobby/ceska-zenska-lobby.php

Frič, P. „Společensko politický kontext aktuálního vývoje neziskového sektoru v ČR.“ In: P. Frič, R. Goulli (eds.) Neziskový sektor v České republice. Výsledky mezinárodního srovnávacího projektu Johns Hopkins University, Praha: Eurolex Bohemia, 2001, 73-125.

Grabbe, H. 2003. „Europeanization Goes East: Power and Uncertainty in the EU Accession Process.“ In: K. Featherstone, C. M. Radaelli (eds.) The Politics of Europeanization. Oxford, New York: Oxford University Press, 303-325.

Greenwood, J. 2003. Interest Representation in the European Union. London: Palgrave.

Hašková, H. 2005. „Czech Women's Civic Organising under the State Socialist Regime, Socio-economic Transformation and the EU Accession Period." Czech Sociological Review 41, 6, 1077-1110.

Hašková, H.; Kř́̌žková, A. 2006. „Rozhodčí a hráči: Vliv socio-ekonomické transformace a evropské integrace na ženské občanské skupiny. “In: H. Hašková, A. Křížková, M. Linková (eds.) Mnohohlasem: vyjednávání ženských prostorů po roce 1989. Praha: Sociologický ústav Akademie věd ČR, 81-102.

Hašková, H.; Kolářová, M. 2003. „Women’s Non-governmental Organisations and Women’s Groups in Left- and Right-wing Social Movements.“ In: H. Hašková, A. Křížková (eds.) Women's Civic and Political Participation in the Czech Republic and the role of European Union Gender Equality and Accession Policies. Praha: Sociologický ústav AV ČR, 45-57.

Helfferich, B.; Kolb, F. 2001. „Multilevel Action Coordination in European Contentious Politics: The Case of the European Women's Lobby.“ In: D. Imig, S. Tarrow (eds.) Contentious Europeans. Protest and Politics in an Emerging Polity. Lanham, Boulder, New York, Oxford: Rowman and Littlefield, 143-162.

Imig, D.; Tarrow, S. eds. 2001. Contentious Europeans. Protest and Politics in an Emerging Polity. Lanham, Boulder, New York, Oxford: Rowman and Littlefield.

Interview 1. Cécile Gréboval, EWL. Brusel: 19. 7. 2006.

Interview 2. Alena Králíková, ČŽL. Praha: 16. 3. 2007.

Kapusta-Pofahl, K.; Hašková, H.; Kolářová, M. 2005. „Influence and Marginality in Formalized and Informal Czech Women's Civic Organizing.“ In T. M. Hall, R. Read (eds.) Changes in the Heart of Europe. Recent Ethnographies of Czechs, Slovak Roma, and Sorbs. Stuttgart: Ibidem-Verlag, 67-92.

Kolářová, M. 2004. Gender in Czech Anarchist Movement. Praha: Subverze.

Linková, M. 2003. „The Institutional Framework for Equal Opportunities Enforcement.“ In: H. Hašková a A. Kř́žzová (eds.) Women's Civic and Political Participation in the Czech Republic and the Role of European Union Gender Equality and Accession Policies. Praha: Sociologický ústav AV ČR, 31-37.

Lorenz-Meyer, D. 2003. „Policy Initiatives and Tools to Promote the Participation of Women and Gender Equality in the Process of the Czech Republic's Accession to the European Union.“ In: H. Hašková, A. Křŕžková (eds.) Women's Civic and Political Participation 
in the Czech Republic and the role of European Union Gender Equality and Accession Policies. Praha: Sociologický ústav AV ČR, 61-85.

Mareš, P.; Kreuzigerová, P.; Marian, J. 2006. Zahranični pomoc v Česku a Československu po listopadu 1989: cíle, formy a výsledky. Praha: Asociace pro mezinárodní otázky.

Marks, G.; McAdam, D. 1999. „On the Relationship of Political Opportunities to the Form of Collective Action: the Case of the European Union." In: D. della Porta, H. Kriesi, D. Rucht (eds.) Social Movements in a Globalizing World. New York: St. Martin's Press, 97-111.

Marksová-Tominová, M. 1999. Formy ženských aktivit. Praha: Gender Studies, nepublikováno.

Martin, A.; Ross, G. 2001. „Trade Union Organizing at the European Level: The Dilemma of Borrowed Resources.“ In: D. Imig, S. Tarrow (eds.) Contentious Europeans. Protest and Politics in an Emerging Polity. Lanham, Boulder, New York, Oxford: Rowman and Littlefield, 53-76.

Musilová, M. 1999. Vývoj politiky rovných př́ležitostí mužů a žen v České republice kontextu evropské integrace. Praha: SOÚ AV ČR.

Radaelli, C. M. 2003. „The Europeanization of Public Policy.“ In: K. Featherstone a C. M. Radaelli (eds.) The Politics of Europeanization. Oxford, New York: Oxford University Press, 27-56.

Risse, T.; Green Cowles, M.; Caporaso, J. 2001. „Europeanization and Domestic Change: Introduction.“ In: M. Green Cowles, J. Caporaso a T. Risse (eds.) Transforming Europe. Europeanization and Domestic Change. Ithaca and London: Cornell University Press, $1-20$.

Rucht, D. 2001. „Lobbying or Protest? Strategies to Influence EU Environmental Policies.“ In: D. Imig, S. Tarrow (eds.) Contentious Europeans. Protest and Politics in an Emerging Polity. Lanham, Boulder, New York, Oxford: Rowman and Littlefield, 125-142.

Schimmelfennig, F. 2002. „Introduction: The Impact of International Organizations on the Central and East European States - Conceptual and Theoretical Issues." In: R. Linden (ed.) Norms and Nannies. The Impact of International Organizations on the Central and East European States. Lanham, Boulder, New York, Oxford: Rowman and Littlefield, $1-29$.

Sikkink, K. 2005. „Patterns of Dynamic Multilevel Governance and the Insider-Outsider Coalition." In: D. della Porta, S. Tarrow (eds.) Transnational Protest and Global Activism. Lanham, Boulder, New York, Oxford: Rowman and Littlefield Publishers, 151-173.

Tarrow, S. 2004. „Center-Periphery Alignments and Political Contention in Late-Modern Europe'." In: Ch. Ansell, G. di Palma (eds.) Restructuring Territoriality: Europe and the United States Compared. Cambridge: Cambridge University Press, 45-64.

Tarrow, S. 2005. The New Transnational Activism. Cambridge: Cambridge University Press. Tilly, Ch.; Tarrow, S. 2007. Contentious Politics. Boulder, London: Paradigm Publishers. Vráblíková, K. 2007. „Jak zkoumat sociální hnutí? Aktivismus ženských skupin v ČR.“ Politologický časopis (v tisku). 


\section{Autoři}

Ondřej Císař pracuje jako odborný asistent na Katedře politologie FSS MU a jako výzkumný pracovník Institutu pro srovnávací politologický výzkum v Brně. Působí také v Ústavu mezinárodních vztahů v Praze, kde vede redakci časopisu Mezinárodní vztahy. Zabývá se mezinárodní politickou teorií, sociálními hnutími a dopady transnacionalizace na sociální hnutí a zájmové skupiny.

Kontakt: cisar@fss.muni.cz

Kateřina Vráblíková je studentkou magisterských studijních programů politologie a sociologie na FSS MU a pracuje jako analytička Institutu pro srovnávací politologický výzkum v Brně.

Kontakt: vrabliko@fss.muni.cz 